\title{
Poziom wiedzy oraz stosunek osób zgłaszających się na szczepienia do konieczności szczepień $w$ dobie pandemii
}

\author{
The level of knowledge and the attitude of people applying for \\ vaccinations to the need to vaccinate during a pandemic
}

AGNIESZKA PIERNIKOWSKA ${ }^{1}$, SYLWIA STALMIRSKA ${ }^{2}$

1 Instytut Nauk o Zdrowiu, Państwowa Uczelnia Zawodowa we Włocławku

2 Centrum Medycznego Medica Sp. Z o.o. Oddział Prof-Med we Włocławku

\section{Streszczenie}

Wstęp. Choroby zakaźne to zagrożenie dla ludzkości, ponieważ są przyczyną wysokiej śmiertelności. Istotną rolę w profilaktyce odgrywają szczepienia ochronne, które na przełomie ostatnich lat zmniejszyły liczbę zachorowań na choroby zakaźne. Prawidłowa realizacja działań profilaktycznych zależy w głównej mierze od świadomości osób podlegających szczepieniu lub opiekunów dzieci. Podjęcie decyzji powinno być poparte wiarygodnym źródłem informacji odnośnie szczepień ochronnych. Wiadomości poparte aktualną wiedzą medyczną należy czerpać od personelu medycznego.

Cel. Celem niniejszej pracy była ocena poziomu wiedzy oraz stosunek osób zgłaszających się na szczepienia do konieczności szczepień w dobie pandemii. Materiał i metody. Materiał badań stanowiło stu pacjentów Centrum Medycznego Medica Sp. z o.o. Oddział Prof.-Med. we Włocławku. Wybrano metodę szacowania oraz sondażu diagnostycznego, zastosowano technikę badawczą w postaci ankiety. Narzędziem badawczym wykorzystanym w pracy był STAI Inwentarz Stanu i Cechy Lęku oraz ankieta własna.

Wyniki. Większość badanych osób oceniał swoją wiedzę na temat szczepień ochronnych jako średnią. Ponad połowa ankietowanych poddała swoje dziecko szczepieniu z własnych przekonań, a w 62\% przypadkach źródłem decyzji o podaniu szczepionki był pediatra. Co trzeci respondent jako źródło decyzji podał pielęgniarkę w punkcie szczepień, a 14\% położną. Rzadziej o podjęciu 
decyzji o szczepieniu decydowała rodzina i znajomi czy media. Z deklaracji ankietowanych wynika, że główną przyczyną poddania dziecka szczepieniom ochronnym była obawa przed zachorowaniem dziecka i powikłaniami, obowiązek wykonywania szczepień ochronnych oraz łagodniejsze przejście choroby po zaszczepieniu. Najrzadziej jako przyczynę realizacji szczepień ochronnych ankietowani wskazywali presję państwa, społeczeństwa i groźbę kary za ich niewykonanie, bezpłatność szczepień czy presję otoczenia. $\mathrm{W}$ opinii większości program szczepień ochronnych w Polsce jest absolutnie konieczny i słuszne jest, że jest on obowiązkowy. Niemal co piąty badany wskazał, że to rodzice powinni mieć możliwość wyboru przeciw jakim chorobom i kiedy chcą zaszczepić swoje dzieci, a 6\% jest przeciwnikiem wykonywania obowiązkowych szczepień ochronnych w Polsce. W opinii większości ankietowanych szczepionki są bezpieczne i zawsze pomagają w zwalczaniu chorób zakaźnych. Zdecydowanie mniej ankietowanych stoi na stanowisku, że przy obecnym poziomie medycyny można ze szczepionek zrezygnować, a żaden $\mathrm{z}$ ankietowanych nie uznał szczepionek za szkodliwych dla zdrowia. Z uzyskanych danych wynika, że obawy i wątpliwości na temat szczepień ochronnych występowały u części z badanych osób zgłaszających się na szczepienia. Wśród zgłaszanych obaw najczęściej wymieniano mogące się pojawić komplikacje i powikłania poszczepienne. Niemal połowa ankietowanych pozytywnie ocenia konieczność realizacji szczepień ochronnych w dobie pandemii, a w 38\% przypadkach pandemia nie miała wpływu na ocenę konieczności realizacji szczepień.

Wnioski. Osoby biorące udział $w$ badaniu mają $w$ większości pozytywny stosunek do szczepień $i$ konieczności ich realizacji w dobie pandemii. Badani przeciętnie lub nisko oceniają swoją wiedzę na temat szczepień ochronnych i zróżnicowana jest ich wiedza na temat wykonywanych obowiązkowych szczepień ochronnych u dzieci.

Słowa kluczowe: szczepienia ochronne, profilaktyka chorób zakaźnych, promocja zdrowia

\section{Summary}

Introduction. Infectious diseases pose a threat to humanity because of high level of mortality. Significant role in prophylaxis took preventive vaccinations which in a past years decreased number of infectious diseases. Correct reali- 
zation of preventive measures depends mainly on persons awareness who are subjected to vaccinations or children guardians. The decision should be supported by a reliable source of information on immunization. Information supported by current medical knowledge should be obtained from medical personnel.

Aim. The aim of this study was to assess the level of knowledge and the attitude of people applying for vaccinations to the need for vaccinations in the time of a pandemic.

Material and methods. Materials for research was 100 patients of Medical Center Medica Ltd. Branch Prof.-Med. in Włocławek. Method taken was and a diagnostic survey, anquiet and estimation method. Used research tool was an Inventory of the State and Features of Anxiety.

Results. Most of respondents assessed their knowledge about preventive vaccines an average. Over the half of respondents vaccinated their child. In $62 \%$ of cases source of decision was pediatrician. Every third respondent said that source of decision was nurse in vaccine point. $14 \%$ of respondents said that midwife convinced them. Family, friends or media less often helped in decision taking. The respondent's declarations showed that the main reason for vaccinating a child was the fear of the child becoming ill, complications, obligatory vaccinations and smoother disease transmission after. The least frequent reason for preventive vaccinations was pressure of the state and society and a penalty for failure. Most people believe that immunization program in Poland is necessary and it is right that is is mandatory. Every fifth respondent pointed that parents should have rights to choose about when and for which diseases their kid will get vaccinated. $6 \%$ are against mandatory vaccination program in Poland. Most of respondents say that vaccines are safety and always help in infectious disease combating. Definitely fewer respondents are of the opinion that with the current level of medicine, vaccines can be dispensed with, and none of the respondents considered vaccines harmful to health. Obtained data shows that fears and doubts on vaccinations appeared on part of respondents that went for vaccine. Among the reported concerns, the most frequently mentioned were complications and complications after vaccination. Over half of respondents positively assesses mandatory vaccines during pandemic. In 38\% cases pandemic situation doesn't have an influence on the necessity to implement vaccinations. 
Conclusions. Most of persons who took a part in researches has a positive opinion about vaccines and the necessity of taking them during pandemic. The respondents have an average or low assessment of their knowledge about preventive vaccinations. Their knowledge about mandatory preventive vaccinations in children is varied.

Keywords: preventive vaccinations, infectious disease prophylaxis, health promotion

\section{Wstęp}

Od wieków ludzkość walczy z chorobami zakaźnymi przenoszonymi przez niezauważalne ludzkim okiem mikroorganizmy. Zagrożenie jest ogromne, gdyż zbierają one śmiertelne żniwo wśród wielomilionowych grup ludności, poprzez tempo ich namnażania oraz drogi przenoszenia. Ewolucja w zakresie szczepień ochronnych pozwala dostrzec i docenić ich istotną rolę w profilaktyce chorób zakaźnych. Na przełomie lat obserwujemy zmniejszenie liczby zachorowań na choroby zakaźne, a nawet wyeliminowanie wielu spośród nich z populacji. Skuteczna profilaktyka nie jest wyłącznie ochroną przed zakażeniem czy łagodniejszym przebiegiem choroby, ale powinna również zmierzać do pełnej ich eradykacji [1].

Korzystne zmiany na rzecz prawidłowej realizacji działań profilaktycznych w dużej mierze zależą od świadomości opiekunów prawnych dzieci oraz osób podlegających szczepieniu. Proces podejmowania decyzji jest złożony i zależy od wielu czynników. Jednym z nich jest wiarygodność źródła informacji odnośnie szczepień [2].

W dzisiejszych czasach większość ludzi szuka informacji w Internecie. Zasób wiadomości, który otrzymujemy, często jest nieprawdziwy lub sprzeczny z aktualną wiedzą medyczną, ponieważ treści zamieszczane są przez niekompetentne osoby. Przyczynia się to do negatywnych postaw wobec wakcynacji. Przeciwnicy szczepień upowszechniają nieufność do instytucji ochrony zdrowia, głoszą teorie spiskowe dotyczące bezpieczeństwa szczepionek, czy też odmawiają szczepień po- 
wołując się na prawa obywatelskie. Zwiększająca się liczba rodziców uchylających się od obowiązku szczepień dzieci zagraża sytuacji epidemiologicznej w przyszłości [3].

Personel medyczny powinien być głównym źródłem wiedzy w kwestii szczepień ochronnych. Na nim spoczywa obowiązek przekazania rzetelnej wiedzy wakcynologicznej w sposób zrozumiały i merytorycznie przystępny [4]. Umiejętność efektywnego komunikowania się z pacjentem lub jego rodzicami oraz tworzenie atmosfery zaufania w relacjach z nimi są równie ważne jak aktualna i obszerna wiedza. Zachowanie empatii względem obaw i wątpliwości oraz merytorycznie przeprowadzona rozmowa o korzyściach i ryzyku immunizacji umożliwia sprawną komunikację i przekonanie do konieczności szczepień nawet najbardziej sceptycznych pacjentów [5].

\section{Cel}

Celem niniejszej pracy była ocena poziomu wiedzy oraz stosunek osób zgłaszających się na szczepienia do konieczności szczepień w dobie pandemii.

\section{Materiały i metody}

Materiał badań stanowiło stu pacjentów Centrum Medycznego Medica Sp. Z o.o. Oddział Prof.-Med. we Włocławku. Wybrano metodę sondażu diagnostycznego i szacowania, zastosowano technikę badawczą w postaci ankiety. Narzędziem badawczym wykorzystanym w pracy był STAI - Inwentarz Stanu i Cechy Lęku oraz ankieta własna.

\section{Wyniki}

Celem badań było poznanie poziomu wiedzy ankietowanych na temat szczepień i ich znaczenia wśród osób zgłaszających się na szczepienia.

W Tabeli I ukazano zestawienie liczbowe i procentowe opinii badanych na temat samooceny własnej wiedzy na temat szczepień ochronnych. 
Tabela 1. Samoocena badanych na temat posiadanej wiedzy o szczepieniach ochronnych

\begin{tabular}{|l|c|c|}
\hline Samoocena wiedzy & n & \% \\
\hline mała & 19 & 19,0 \\
\hline średnia & 65 & 65,0 \\
\hline duża & 12 & 12,0 \\
\hline $\begin{array}{l}\text { nie posiadam żadnej } \\
\text { wiedzy na temat } \\
\text { szczepień }\end{array}$ & 4 & 4,0 \\
\hline Razem & 100 & 100,0 \\
\hline
\end{tabular}

Źródło: Wyniki badań własnych, Włocławek 2021.

Większość badanych osób oceniał swoją wiedzę na temat szczepień ochronnych jako średnią $(65 \%, n=65)$, a co piąty zadeklarował, że jest ona mała $(19 \%, n=19)$. Posiadanie dużej wiedzy o szczepieniach w swojej samoocenie miało $12 \%$ respondentów ( $n=12)$, a 4\% przyznało, że nie ma żadnej wiedzy w tym temacie $(n=4)$.

W Tabeli II ukazano dane liczbowe i procentowe weryfikujące poziom wiedzy ankietowanych na temat szczepień. Respondentów zapytano, które ze wskazanych szczepionek w ankiecie były obowiązkowe w 2020 r. zgodnie z Programem Szczepień Ochronnych ustalonych przez Ministerstwo Zdrowia.

Tabela 2. Wiedza badanych na temat obowiązkowych szczepień ochronnych w 2020 r. zgodnie z Programem Szczepień Ochronnych

\begin{tabular}{|l|c|c|}
\hline \multirow{2}{*}{ Szczepienia ochronne } & \multicolumn{2}{|c|}{ Szczepienie obowiązkowe } \\
\cline { 2 - 3 } & $\mathbf{n}$ & $\mathbf{\%}$ \\
\hline Gruźlica & 74 & 74,0 \\
\hline WZW B & 48 & 48,0 \\
\hline WZW A & 8 & 8,0 \\
\hline
\end{tabular}




\begin{tabular}{|l|c|c|}
\hline Ospa wietrzna & 28 & 28,0 \\
\hline Haemophilus influenzae & 21 & 21,0 \\
\hline MMR (odra, świnka, różyczka) & 55 & 55,0 \\
\hline Rotawirusy & 28 & 28,0 \\
\hline Błonica, tężec, krztusiec & 51 & 51,0 \\
\hline Poliomyelitis & 29 & 29,0 \\
\hline Meningokoki & 4 & 4,0 \\
\hline Pneumokoki & 16 & 16,0 \\
\hline Nie mam wiedzy na ten temat & 14 & 14,0 \\
\hline
\end{tabular}

Źródło: Wyniki badań własnych, Włocławek 2021.

Zgodnie z Programem Szczepień Ochronnych na 2020 r. obowiązkowymi szczepieniami były szczepienia przeciw gruźlicy, WZW B, Haemophilus influenzae, MMR, błonica, tężec i krztusiec, poliomyelitis i pneumokoki. W 2021 r. do obowiązkowych dodano także szczepienie przeciw Rotawirusom. Z danych zawartych w Tabeli wynika, że gruźlicę jako obowiązkowe szczepienie poprawnie określiło 74\% ankietowanych ( $\mathrm{n}=74)$, WZW B - 48\% (n=48), Haemeophilus influenzae tylko 21\% ( $n=21)$, MMR - 55\% ( $n=55)$, błonicę tężec i krztusiec - 51\% ( $n=51)$, poliomyelitis - $29 \%(\mathrm{n}=29)$, a pneumokoki tylko $16 \%(\mathrm{n}=16)$.

Drugim celem badań było poznanie stosunku badanych osób zgłaszających się na szczepienia do konieczności ich realizacji w dobie pandemii.

Na początek dokonano analizy realizacji szczepień ochronnych u dzieci osób badanych. W Tabeli III ukazano zestawienie liczbowe i procentowe odpowiedzi na pytanie o realizację szczepień ochronny u dzieci. 
Tabela 3. Realizacja szczepień ochronnych u dzieci osób badanych

\begin{tabular}{|l|c|c|}
\hline Realizacja szczepień u dzieci & $\mathbf{n}$ & $\mathbf{\%}$ \\
\hline tak & 96 & 96,0 \\
\hline nie & 2 & 2,0 \\
\hline braki danych & 2 & 2,0 \\
\hline Razem & 100 & 100,0 \\
\hline
\end{tabular}

Źródło: Wyniki badań własnych, Włocławek 2021.

W zdecydowanej większości, bo w 96\% (n=96) ankietowani poddali swoje dzieci szczepieniom ochronnym. Brak wypełnienia tego obowiązku występował u $2 \%$ respondentów ( $\mathrm{n}=2$ ).

W Tabeli IV ukazano zestawienie liczbowe i procentowe źródeł mających decydujący wpływ na podjęcie decyzji o zaszczepieniu swojego dziecka. Pytanie miało charakter wielokrotnego wyboru, dlatego też jego wyniki nie sumują się do $100 \%$.

Tabela 4. Źródła decydujące o wpływie na podjęcie decyzji o zaszczepieniu dziecka badanych

\begin{tabular}{|l|c|c|}
\hline Źródła & $\mathbf{n}$ & $\mathbf{\%}$ \\
\hline pediatra & 62 & 62,0 \\
\hline pielęgniarka w punkcie szczepień & 35 & 35,0 \\
\hline położona & 14 & 14,0 \\
\hline rodzina, znajomi & 11 & 11,0 \\
\hline media & 10 & 10,0 \\
\hline własne przekonania & 57 & 57,0 \\
\hline inne & 1 & 1,0 \\
\hline
\end{tabular}

Źródło: Wyniki badań własnych, Włocławek 2021. 
Ponad połowa (57\%, $\mathrm{n}=57)$ ankietowanych poddała swoje dziecko szczepieniu z własnych przekonań, a w $62 \%$ przypadkach $(\mathrm{n}=62)$ źródłem decyzji o podaniu szczepionki był pediatra. Co trzeci respondent (35\%, n=35) jako źródło decyzji podał pielęgniarkę w punkcie szczepień, a 14\% (n=14) położną. Rzadziej o podjęciu decyzji o szczepieniu decydowała rodzina i znajomi $(11 \%, \mathrm{n}=11)$ i media $(10 \%, \mathrm{n}=10)$.

W Tabeli V ukazano zestawienie liczbowe i procentowe odpowiedzi na temat głównych powodów przemawiających za zaszczepieniem dziecka. Pytanie miało charakter wielokrotnego wyboru, dlatego też jego wyniki nie sumują się do $100 \%$.

Tabela 5. Główne powody szczepienia dziecka w opinii badanych

\begin{tabular}{|l|c|c|}
\hline Powody szczepienia & n & \% \\
\hline obowiązek wykonywania szczepień ochronnych & 51 & 51,0 \\
\hline obawa przed zachorowaniem dziecka i powikłaniami & 55 & 55,0 \\
\hline łagodniejsze przebycie choroby po zaszczepieniu & 48 & 48,0 \\
\hline fakt, że też byłem/am szczepiony/a & 22 & 22,0 \\
\hline przekonanie o słuszności szczepień & 29 & 29,0 \\
\hline presja otoczenia & 3 & 3,0 \\
\hline Presja państwa, społeczeństwa, groźba kary & 6 & 6,0 \\
\hline są darmowe & 5 & 5,0 \\
\hline
\end{tabular}

Źródło: Wyniki badań własnych, Włocławek 2021.

Z deklaracji ankietowanych wynika, że główną przyczyną poddania dziecka szczepieniom ochronnym była obawa przed zachorowaniem dziecka i powikłaniami $(55 \%, n=55)$ i obowiązek wykonywania szczepień ochronnych $(51 \%, \mathrm{n}=51)$ oraz łagodniejsze przejście choroby po zaszczepieniu (48\%, n=48). Wśród kolejnych przyczyn ankietowani wskazywali także na przekonanie o słuszności szczepień (29\%, n=29), fakt, że też się jest zaszczepionym $(22 \%, \mathrm{n}=22)$. Najrzadziej jako przyczynę realizacji szczepień ochronnych ankietowani wskazywali presję 
państwa, społeczeństwa i groźbę kary za ich niewykonanie $(6 \%, n=6)$, bezpłatność szczepień $(5 \%, n=5)$ czy presję otoczenia $(3 \%, n=3)$.

W Tabeli VI ukazano zestawienie liczbowe i procentowe opinii badanych na temat szczepień ochronnych i ich realizacji.

Tabela 6. Opinie o obowiązkowych szczepieniach ochronnych badanych

\begin{tabular}{|l|c|c|}
\hline & n & \% \\
\hline $\begin{array}{l}\text { Program szczepień ochronnych jest absolutnie } \\
\text { konieczny i słusznym jest, że jest obowiązkowy }\end{array}$ & 69 & 69,0 \\
\hline $\begin{array}{l}\text { W Polsce nie powinno być obowiązku wykonywania } \\
\text { szczepień ochronnych }\end{array}$ & 6 & 6,0 \\
\hline $\begin{array}{l}\text { Rodzice powinni mieć możliwość wyboru przeciw jakim } \\
\text { chorobom i kiedy chcą zaszczepić swoje dzieci }\end{array}$ & 18 & 18,0 \\
\hline $\begin{array}{l}\text { Nie mam zdania na temat konieczności wykonywania } \\
\text { szczepień ochronnych }\end{array}$ & 7 & 7,0 \\
\hline Razem & 100 & 100,0 \\
\hline
\end{tabular}

Źródło: Wyniki badań własnych, Włocławek 2021.

W opinii większości, bo 69\% (n=69) ankietowanych program szczepień ochronnych w Polsce jest absolutnie konieczny i słuszne jest, że jest on obowiązkowy. Niemal co piąty badany $(18 \%, n=18)$ wskazał, że to rodzice powinni mieć możliwość wyboru przeciw jakim chorobom i kiedy chcą zaszczepić swoje dzieci, a 6\% $(\mathrm{n}=6)$ jest przeciwnikiem wykonywania obowiązkowych szczepień ochronnych w Polsce. Brak opinii na powyższy temat charakteryzował $7 \%$ respondentów.

W Tabeli VII sprawdzono czy poziom lęku ankietowanych różnicuje ich opinie na temat obowiązkowych szczepień ochronnych. 
Tabela 7. Opinie o obowiązkowych szczepieniach ochronnych badanych a poziom lęku badanych

\begin{tabular}{|c|c|c|c|c|c|c|}
\hline & & $\mathbf{n}$ & $\mathbf{M}$ & SD & $\begin{array}{l}\text { Błąd } \\
\text { stan- } \\
\text { dar- } \\
\text { dowy }\end{array}$ & $\begin{array}{l}\text { Jedno- } \\
\text { czynni- } \\
\text { kowa } \\
\text { ANOVA }\end{array}$ \\
\hline \multirow[t]{5}{*}{$\begin{array}{l}\text { Lęk } \\
\text { jako } \\
\text { stan }\end{array}$} & $\begin{array}{l}\text { Program szczepień } \\
\text { ochronnych jest absolutnie } \\
\text { konieczny i słusznym jest, } \\
\text { że jest obowiązkowy }\end{array}$ & 69 & 48,68 & 3,632 & 437 & \multirow[t]{5}{*}{$\begin{array}{l}F=1,659 \\
p=0,181\end{array}$} \\
\hline & $\begin{array}{l}\text { W Polsce nie powinno być } \\
\text { obowiązku wykonywania } \\
\text { szczepień ochronnych }\end{array}$ & 6 & 50,00 & 1,789 & ,730 & \\
\hline & $\begin{array}{l}\text { Rodzice powinni mieć } \\
\text { możliwość wyboru przeciw } \\
\text { jakim chorobom i kiedy } \\
\text { chcą zaszczepić swoje } \\
\text { dzieci }\end{array}$ & 18 & 47,94 & 3,780 & 891 & \\
\hline & $\begin{array}{l}\text { Nie mam zdania na temat } \\
\text { konieczności wykonywania } \\
\text { szczepień ochronnych }\end{array}$ & 7 & 46,00 & 3,916 & 1,480 & \\
\hline & Ogółem & 100 & 48,44 & 3,641 & ,364 & \\
\hline \multirow[t]{5}{*}{$\begin{array}{l}\text { Lęk } \\
\text { jako } \\
\text { cecha }\end{array}$} & $\begin{array}{l}\text { Program szczepień } \\
\text { ochronnych jest absolutnie } \\
\text { konieczny i słusznym jest, } \\
\text { że jest obowiązkowy }\end{array}$ & 69 & 46,45 & 3,483 & ,419 & \multirow[t]{5}{*}{$\begin{array}{l}F=0,995 \\
p=0,399\end{array}$} \\
\hline & $\begin{array}{l}\text { W Polsce nie powinno być } \\
\text { obowiązku wykonywania } \\
\text { szczepień ochronnych }\end{array}$ & 6 & 49,00 & 2,366 & ,966 & \\
\hline & $\begin{array}{l}\text { Rodzice powinni mieć } \\
\text { możliwość wyboru przeciw } \\
\text { jakim chorobom i kiedy } \\
\text { chcą zaszczepić swoje } \\
\text { dzieci }\end{array}$ & 18 & 47,06 & 4,399 & 1,037 & \\
\hline & $\begin{array}{l}\text { Nie mam zdania na temat } \\
\text { konieczności wykonywania } \\
\text { szczepień ochronnych }\end{array}$ & 7 & 46,14 & 4,488 & 1,696 & \\
\hline & Ogółem & 100 & 46,69 & 3,684 &, 368 & \\
\hline
\end{tabular}

Źródło: Wyniki badań własnych, Włocławek 2021. 
Test jednoczynnikowej ANOVA nie wykazał istotnych różnic w opiniach na temat szczepień ochronnych badanych a poziomem lęku jako cechą i stanem ( $\mathrm{p}>0,05)$.

W Tabeli VIII ukazano opinie badanych o szczepieniach ochronnych i ich wpływie na zdrowie.

Tabela 8. Opinie badanych o szczepieniach ochronnych

\begin{tabular}{|l|c|c|}
\hline & $\mathbf{n}$ & $\mathbf{\%}$ \\
\hline $\begin{array}{l}\text { Szczepionki są bezpieczne i zawsze pomagają } \\
\text { w zwalczaniu chorób zakaźnych }\end{array}$ & 78 & 78,0 \\
\hline Szczepionki są szkodliwe dla zdrowia & 0 & 0,0 \\
\hline $\begin{array}{l}\text { Przy obecnym poziomie medycyny można z nich } \\
\text { zrezygnować }\end{array}$ & 21 & 21,0 \\
\hline Braki danych & 1 & 1,0 \\
\hline Razem & 100 & 100,0 \\
\hline
\end{tabular}

Źródło: Wyniki badań własnych, Włocławek 2021.

W opinii większości ankietowanych $(78 \%, \mathrm{n}=78)$ szczepionki są bezpieczne i zawsze pomagają w zwalczaniu chorób zakaźnych. Zdecydowanie mniej ankietowanych, bo $21 \%(n=21)$ stoi na stanowisku, że przy obecnym poziomie medycyny można ze szczepionek zrezygnować, a żaden z ankietowanych nie uznał szczepionek za szkodliwych dla zdrowia.

W Tabeli IX ukazano czy poziom lęku ankietowanych różnicuje ich opinie na temat szczepień ochronnych i ich wpływie na zdrowie. 
Tabela 9. Opinie badanych o szczepieniach ochronnych a poziom lęku badanych

\begin{tabular}{|c|c|c|c|c|c|c|}
\hline & & $\mathbf{n}$ & $\mathbf{M}$ & SD & $\begin{array}{l}\text { Błąd } \\
\text { stan- } \\
\text { dar- } \\
\text { dowy }\end{array}$ & $\begin{array}{l}\text { Jedno- } \\
\text { czynni- } \\
\text { kowa } \\
\text { ANOVA }\end{array}$ \\
\hline \multirow[t]{3}{*}{$\begin{array}{l}\text { Lęk } \\
\text { jako } \\
\text { stan }\end{array}$} & $\begin{array}{l}\text { Szczepionki są bezpieczne } \\
\text { i zawsze pomagają } \\
\text { w zwalczaniu chorób } \\
\text { zakaźnych }\end{array}$ & 78 & 48,69 & 3,708 & ,420 & \multirow[t]{3}{*}{$\begin{array}{l}F=2,160 \\
p=0,145\end{array}$} \\
\hline & $\begin{array}{l}\text { Przy obecnym poziomie } \\
\text { medycyny można z nich } \\
\text { zrezygnować }\end{array}$ & 21 & 47,38 & 3,309 & ,722 & \\
\hline & Ogółem & 99 & 48,41 & 3,651 & ,367 & \\
\hline \multirow[t]{3}{*}{$\begin{array}{l}\text { Lęk } \\
\text { jako } \\
\text { cecha }\end{array}$} & $\begin{array}{l}\text { Szczepionki są bezpieczne } \\
\text { i zawsze pomagają } \\
\text { w zwalczaniu chorób } \\
\text { zakaźnych }\end{array}$ & 78 & 46,28 & 3,392 & ,384 & \multirow[t]{3}{*}{$\begin{array}{l}F=3,529 \\
p=0,063\end{array}$} \\
\hline & $\begin{array}{l}\text { Przy obecnym poziomie } \\
\text { medycyny można z nich } \\
\text { zrezygnować }\end{array}$ & 21 & 47,95 & 4,376 & ,955 & \\
\hline & Ogółem & 99 & 46,64 & 3,663 & 368 & \\
\hline
\end{tabular}

Źródło: Wyniki badań własnych, Włocławek 2021.

Test jednoczynnikowej ANOVA nie wykazał istotnych różnic w opiniach na temat szczepień ochronnych badanych a poziomem lęku jako cechą i stanem $(\mathrm{p}>0,05)$.

W Tabeli X ukazano zestawienie liczbowe i procentowe odpowiedzi na pytanie o obawy ankietowanych związane ze szczepieniem. Było to pytanie wielokrotnego wyboru, dlatego też jego wyniki nie sumują się do $100 \%$. 
Tabela 10. Obawy i wątpliwości badanych na temat szczepień ochronnych

\begin{tabular}{|l|c|c|}
\hline & n & $\mathbf{~ \% ~}$ \\
\hline tak, obawiam się komplikacji i powikłań & 38 & 38,0 \\
\hline $\begin{array}{l}\text { tak, martwi mnie fakt podawania dużej ilości szczepionek } \\
\text { w krótkim czasie }\end{array}$ & 12 & 12,0 \\
\hline tak, szczepionki zawierają niebezpieczne związki & 5 & 5,0 \\
\hline tak, gdyż nie wierzę w ich skuteczność & 3 & 3,0 \\
\hline nie, nie mam żadnych obaw i wierzę w ich skuteczność & 39 & 39,0 \\
\hline nie mam zdania na ten temat & 12 & 12,0 \\
\hline
\end{tabular}

Źródło: Wyniki badań własnych, Włocławek 2021.

Z uzyskanych danych wynika, że obawy i wątpliwości na temat szczepień ochronnych występowały u części z badanych osób zgłaszających się na szczepienia, a brak obaw z nimi związanych charakteryzował 39\% (n=39) respondentów. Wśród zgłaszanych obaw najczęściej wymieniano mogące się pojawić komplikacje i powikłania poszczepienne (38\%, $\mathrm{n}=38)$, fakt podawania dużej ilości szczepionek w krótkim czasie (12\%, $\mathrm{n}=12$ ) i rzadziej zawarte w szczepionkach niebezpieczne związki (5\%, $\mathrm{n}=5)$ i brak wiary w skuteczność szczepionek (3\%, n=3). W badanej grupie $12 \%(n=12)$ respondentów nie miało zdania na omawiany temat.

Kolejne pytanie dotyczyło opinii ankietowanych o konieczności wykonywania szczepień ochronnych w czasie pandemii COVID-19. Zestawienie liczbowe i procentowe odpowiedzi ukazuje Tabela XI.

Tabela 11. Opinie o konieczności wykonywania szczepień ochronnych w czasie pandemii COVID-19

\begin{tabular}{|l|c|c|}
\hline Szczepienia w dobie pandemii & n & \% \\
\hline oceniam pozytywnie & 45 & 45,0 \\
\hline oceniam negatywnie & 17 & 17,0 \\
\hline pandemia nie miała wpływu na mają ocenę & 38 & 38,0 \\
\hline Razem & 100 & 100,0 \\
\hline
\end{tabular}

Źródło: Wyniki badań własnych, Włocławek 2021. 
Niemal połowa ankietowanych $(45 \%, n=45)$ pozytywnie ocenia konieczność realizacji szczepień ochronnych $\mathrm{w}$ dobie pandemii, a w 38\% przypadkach $(\mathrm{n}=38)$ pandemia nie miała wpływu na ocenę konieczności realizacji szczepień. Kolejne 17\% (n=17) negatywnie oceniło konieczność realizacji szczepień w czasie pandemii COVID-19.

Sprawdzono także czy poziom lęku badanych różnicuje opinie o konieczności wykonywania szczepień ochronnych w czasie pandemii COVID-19. Wyniki testu jednoczynnikowej ANOVA ukazuje Tabela XII.

Tabela 12. Wpływ poziomu lęku na opinie o konieczności wykonywania szczepień ochronnych w czasie pandemii COVID-19

\begin{tabular}{|c|c|c|c|c|c|c|}
\hline & & $\mathbf{N}$ & $\begin{array}{c}\text { Śred- } \\
\text { nia }\end{array}$ & $\begin{array}{l}\text { Odchy- } \\
\text { lenie } \\
\text { standar- } \\
\text { dowe }\end{array}$ & $\begin{array}{l}\text { Błąd } \\
\text { standar- } \\
\text { dowy }\end{array}$ & $\begin{array}{l}\text { Jedno- } \\
\text { czynni- } \\
\text { kowa } \\
\text { ANOVA }\end{array}$ \\
\hline \multirow{4}{*}{$\begin{array}{l}\text { Lęk } \\
\text { jako } \\
\text { stan }\end{array}$} & oceniam pozytywnie & 45 & 49,11 & 3,827 & ,571 & \multirow{4}{*}{$\begin{array}{l}F=1,450 \\
p=0,240\end{array}$} \\
\hline & oceniam negatywnie & 17 & 48,12 & 3,756 & ,911 & \\
\hline & $\begin{array}{l}\text { pandemia nie miała } \\
\text { wpływu na moją } \\
\text { ocenę }\end{array}$ & 38 & 47,79 & 3,306 & ,536 & \\
\hline & Ogółem & 100 & 48,44 & 3,641 & 364 & \\
\hline \multirow{4}{*}{$\begin{array}{l}\text { Lęk } \\
\text { jako } \\
\text { cecha }\end{array}$} & oceniam pozytywnie & 45 & 46,60 & 3,136 & ,468 & \multirow{4}{*}{$\begin{array}{l}F=2,964 \\
p=0,056\end{array}$} \\
\hline & oceniam negatywnie & 17 & 48,53 & 3,520 & ,854 & \\
\hline & $\begin{array}{l}\text { pandemia nie miała } \\
\text { wpływu na moją } \\
\text { ocenę }\end{array}$ & 38 & 45,97 & 4,143 & 672 & \\
\hline & Ogółem & 100 & 46,69 & 3,684 & 368 & \\
\hline
\end{tabular}

Źródło: Wyniki badań własnych, Włocławek 2021.

Test jednoczynnikowej ANOVA nie wykazał istotnych różnic w opinii ankietowanych na temat konieczności wykonywania szczepień ochronnych w czasie pandemii COVID-19 ( $p>0,05)$. 


\section{Dyskusja}

Celem badań było poznanie wpływu pandemii Covid-19 i lęku przed chorobami zakaźnymi na poziom wyszczepialności. Badania własne wykonane zostało na 100 osobowej grupie pacjentów. W grupie badawczej znalazło się 58,0\% osób powyżej 35 lat oraz 21,0\% osób między 30 a 35 rokiem życia. Większość, bo 77,0\% stanowiły kobiety. Badani legitymowali się najczęściej wykształceniem wyższym $(46,0 \%)$ i średnim $(42,0 \%)$ i w 55,0\% zamieszkiwali miasto. Ankietowani to głównie osoby pracujące $(89,0 \%)$ mające $1(56,0 \%)$ lub dwoje dzieci $(34,0 \%)$.

Z badań własnych wynika, że ankietowani w 96,0\% realizują szczepienia obowiązkowe u dzieci, a nie czyni tego tylko 2,0\% badanych. Powyższe jest zgodne z badaniami ogólnopolskimi. Z badań CBOS wynika bowiem, że 3\% dorosłych Polaków, które mają dzieci deklaruje, że ich dziecko nie zostało poddane sczepieniu obowiązkowemu przeciw chorobie zakaźnej [6]. Z analizy materiału Pieszki i wsp. wynika, że większość rodziców (86\%) szczepi swoje dzieci zgodnie z kalendarzem szczepień. W pozostałych $14 \%$ rodzice nie szczepili swoich dzieci głównie z powodu choroby dziecka. Jednak w 12\% przypadków termin szczepienia był celowo przesuwany [7].

Na decyzję o szczepieniu dziecka wpłynął pediatra $(62,0 \%)$ i własne przekonania (57,0\%). Podobnie w badaniach Szalonki [8], gdzie ok $70,0 \%$ respondentów czerpie informacje o szczepieniach od personelu medycznego. W badaniu Szkopek i Dębowskiej [9] 35\% badanych potwierdziło, że rodzice podejmujący decyzję o zaszczepieniu swojego dziecka powinni sięgać przede wszystkim po wiedzę czerpaną od personelu medycznego. Wyniki przeprowadzonego badania, podobnie jak wyniki innych współczesnych prac badawczych jako główne źródło wiedzy wskazują jednak Internet $[10,11]$.

Głównym powodem szczepienia w badaniach własnych była obawa przed zachorowaniem dziecka $(55,0 \%)$, obowiązek ich wykonywania $(51,0 \%)$ oraz łagodniejsze przebycie choroby po zaszczepieniu $(48,0 \%)$. 
Badani to w większości zwolennicy szczepień, którzy uważają, że program szczepień ochronnych jest absolutnie konieczny i słusznym jest, że jest obowiązkowy $(69,0 \%)$, a $18,0 \%$ wskazało, że to rodzice powinni decydować o szczepieniu swojego dziecka. Przeciwnicy szczepień stanowili 6,0\% badanych. W badaniach Szalonki [8] wykazano, że $51,0 \%$ badanych jest zwolennikiem szczepień i przeciwników szczepień było zdecydowanie więcej niż w badaniach własnych, bo 41,0\%.

Badana grupa wskazała, że szczepionki są bezpieczne i pomagają w zwalczaniu chorób zakaźnych (78,0\%), a 21,0\% przyznało, że przy obecnym rozwoju medycyny można by było z nich zrezygnować. Żaden z ankietowanych nie wskazał, że szczepionki szkodzą zdrowiu. Nie duży odsetek respondentów obawiał się komplikacji i powikłań po szczepieniach (38,0\%), a 39,0\% wskazało, że nie ma obaw związanych ze szczepieniami. Obawę przed powikłaniami poszczepiennymi odczuwał nieco większy odsetek respondentów Szalonki [52], bo 48,0\%. W porównaniu z innymi badaniami jest to wynik wysoki. Przykładem jest badanie zaufania rodziców do systemu szczepień ochronnych przeprowadzone w osiemnastu krajach europejskich, w 2019 roku. Respondenci z różnych państw deklarowali swoje stanowisko dotyczące szczepień ochronnych. Wśród ankietowanych było 56\% zwolenników niemających wątpliwości co do zaszczepienia swojego dziecka [12].

Ankietowani wskazali, że szczepienia ochronne w dobie pandemii należy wykonywać $(45,0 \%)$, a 38,0\% uważa, że pandemia nie wpływa na ich ocenę wobec realizacji szczepień ochronnych.

Poziom lęku jako stan i jako cecha nie różnicował opinii o obowiązkowych szczepieniach ochronnych ( $p>0,05)$, konieczności ich wykonywania $(p>0,05)$ i opinii o wykonywaniu szczepień ochronnych w dobie pandemii. Inne wyniki uzyskała m.in. Szkopek i Dębowska prowadzonych wśród kobiet w ciąży. Podczas analizy związków między skalami lęku a opiniami na temat szczepionek i szczepień stwierdzono istotną ( $\mathrm{p}<0,05)$, choć niską, ujemną korelację $(-0,1499)$ między surowym wynikiem skali lęku jako stanu a odpowiedzią na pytanie o decyzję zaszczepienia dziecka. Stwierdzono istotną $(\mathrm{p}<0,05)$, choć niską, do- 
datnią korelację $(0,14950)$ między surowym wynikiem skali lęku jako cechy a odpowiedzią na to samo pytanie [9]. Potwierdzenie, że lęk jako cecha w większym stopniu niż stan powoduje zmianę w postrzeganiu szczepień, może być wykorzystywane przede wszystkim przez pracowników ochrony zdrowia. Lekarz pierwszego kontaktu, ginekolog, położna i pielęgniarka to personel medyczny, który jako pierwszy ma kontakt z przyszłą matką i to on najbardziej wpływa na podjęcie przez nią decyzji na temat zaszczepienia dziecka. Potwierdza to wynik badania własnego oraz innych analizujących temat szczepień ochronnych [13].

Z uzyskanych danych wynika, że respondenci średnio oceniają swój poziom wiedzy na temat szczepień ochronnych (65,0\%), a 19,0\% wskazała, że jest ona mała. Z badań wynika, że nie wszyscy ankietowani mieli wiedzę na temat obowiązkowych szczepień ochronnych, gruźlicę jako obowiązkowe szczepienie poprawnie określiło 74\% ankietowanych (n=74), WZW B - 48\% (n=48), Haemophilus influenzae tylko $21 \%$ $(n=21)$, MMR - 55\% ( $n=55)$, błonicę tężec i krztusiec - 51\% ( $n=51)$, poliomyelitis - 29\% ( $n=29)$, a pneumokoki tylko $16 \%(n=16)$. Nieco inne wyniki uzyskała Pieszka i wsp. badająca rodziców dzieci do drugiego roku życia. $Z$ badań tych wynika, że wiedza rodziców na temat szczepień jest wysoka, a choroby zakaźne przeciw którym szczepione są dzieci są im znane [8]. Analizując przeprowadzone badania należy wskazać, że istnieje deficyt informacji u rodziców na temat szczepień zalecanych. Wskazane jest przeprowadzenie edukacji rodziców przez pracowników służby zdrowia - z dużym prawdopodobieństwem zwiększyłoby to wyszczepialność.

\section{Wnioski}

Badani mają w większości pozytywny stosunek do szczepień i konieczności ich realizacji w dobie pandemii. Pandemia oraz poziom lęku nie różnicują opinii respondentów na temat szczepień ochronnych.

Badani przeciętnie lub nisko oceniają swoją wiedzę na temat szczepień ochronnych i zróżnicowana jest ich wiedza na temat wykonywanych obowiązkowych szczepień ochronnych u dzieci. 


\section{Zalecenia dla praktyki pielęgniarskiej}

Decydujący wpływ na postawy i wiedzę rodziców dotyczącą szczepień ochronnych mają przedstawiciele środowiska medycznego poprzez swoją aktywną edukację. Rola dydaktyczna stanowi integralną część realizacji celów polityki zdrowotnej państwa. W przypadku braku zgody rodzica na szczepienia dobrze przekazana, sprawdzona wiedza, oparta na dowodach naukowych i poparta badaniami może sprawić, że osoby sceptycznie nastawione do realizacji kalendarza szczepień otrzymują wiadomości ułatwiające podjęcie świadomej i właściwej dla nich decyzji. Przekonanie pacjenta do ich zastosowania pozwala uniknąć nie tylko samej choroby, lecz także niebezpiecznych powikłań im towarzyszących.

\section{Bibliografia/ Bibliography:}

1. Braczkowska B., Kowalska M. Uwarunkowania uchylania się od szczepień. Przegląd Epidemiologiczny 2017;71(2):227-236.

2. Bernatowska E. Obowiązkowy program szczepień ochronnych w 2019 roku - z jakimi wyzwaniami przyjdzie się zmierzyć i czy powróci zaufanie do szczepień? Standardy medyczne. Pediatria. 2019;16:155-160.

3. Marchewka A.K., Majewska A. Działalność ruchu antyszczepionkowego, rola środków masowego komunikowania oraz wpływ poglądów religijnych na postawę wobec szczepień ochronnych. Post.Mikrobiol.2015,54(2):95-102.

4. Rogalska J., Augustynowicz E. Źródła informacji oraz wiedza rodziców na temat szczepień ochronnych w Polsce. Przegląd epidemiologiczny. 2010;1:83-90.

5. Bednarek A., Zarzycka D.: Potrzeba i założenia nowoczesnej edukacji na przykładzie szczepień ochronnych. Probl. Hig. Epidemiol. 2015, 96(1): 1-7.

6. Gwiazda M. Polacy o obowiązku szczepienia dzieci. Komunikat z badań CBOS. 2017; 100. 
7. Pieszka M., Waksmańsa W., Woś H. Wiedza rodziców do drugiego roku życia na temat szczepień ochronnych. Medycyna Ogólna i Nauki o Zdrowiu. 2016;22;3:221-226.

8. Szalonka A. Społeczne uwarunkowania szczepień w Polsce w świetle badań ankietowych. [w:] W. Nowak, K. Szalonka (red.). Zdrowie i style życia. Determinanty długości życia. Uniwersytet Wrocławski, Wrocław 2020:389-404.

9. Szkopek P., Dębowska M. D. Poziom lęku a postawa wobec obowiązkowych szczepień u kobiet w ciąży. Psychiatria. 2021;18(1);1-7.

10. Modanloo S., Stacey D., Dunn S. i wsp. Parent resources for early childhood vaccination: An online environmental scan. Vaccine. 2019;37(51):74937500 .

11. Bianco A., Mascaro V., Zucco R. i wsp. Parent perspectives on childhood vaccination: How to deal with vaccine hesitancy and refusal? Vaccine. 2019;37(7):984-990.

12. Hadjipanayis A., Esso Dv., Torso Sd. i wsp. Vaccine confidence among parents: large scale study in eighteen European countries. Vaccine. 2020;38(6):1505-1512.

13. Kochman D., Rudzińska T. Znaczenie edukacji rodziców w kontekście szczepień obowiązkowych i zalecanych u dzieci w wieku 0-2 lat. Problemy Pielęgniarstwa. 2008;16(1-2):163-172. 